Review

\title{
Roman agriculture in the conventus Bracaraugustanus (NW Iberia)
}

\author{
João Pedro Tereso ${ }^{\mathrm{a}, *}$, Pablo Ramil-Rego ${ }^{\mathrm{b}}$, Rubim Almeida-da-Silva ${ }^{\mathrm{c}}$ \\ ${ }^{\text {a } C I B I O}$ (Research Center In Biodiversity and Genetic Resources), Universidade do Porto, Faculdade de Ciências, Departamento de Biologia, Edificio FC4, Sala 1A, \\ Rua do Campo Alegre, s/n, 4169-007 Porto, Portugal \\ ${ }^{\mathrm{b}}$ IBADER (Instituto de Biodiversidade Agraria e Desenvolvemento Rural), GI-1934, Territorio-Biodiversidade, Lab Botánica E Bioxeografia, Campus Universitario, \\ $s / n$, E-27002 Lugo (Galicia), Spain \\ ${ }^{\mathrm{C}}$ University of Porto, Dept. of Biology E' CIBIO, Edificio FC4, Rua do Campo Alegre, s/n, 4169-007 Porto, Portugal
}

\section{A R T I C L E I N F O}

\section{Article history:}

Received 7 May 2012

Received in revised form 3 January 2013

Accepted 10 January 2013

\section{Keywords:}

Roman

Agriculture

Archaeobotany

Conventus Bracaraugustanus

Northwest Iberia

\begin{abstract}
A B S T R A C T
A review of archaeobotanical data, together with new, still unpublished data, from Roman sites in conventus Bracaraugustanus suggests the Romanization of the northwest Iberia brought little changes to the agricultural strategies of local communities in indigenous-type settlements. The main crops remain the same as in the Iron Age: Triticum aestivum/durum, Panicum miliaceum, Hordeum vulgare subsp. vulgare, Triticum turgidum subsp. dicoccum and T. aestivum subsp. spelta, Avena and Vicia faba. The first secure reference for the cultivation of Secale cereale in the region comes from a Roman context, suggesting that it was introduced in this period, although it probably remained a minor crop.

It is possible that during Roman times we have the first evidences for the cultivation of vine in the southernmost part of the conventus, near the river Douro but there are no signs of olive trees cultivation.

Overall, not all the innovations usually attributed to the Romans are recorded in northwest Iberia. This fits the general scenario of a region which maintained its rural character, although with some differences in territorial organization. However, the fact that almost all the sites with fruits and seeds are indigenous-type settlements (hillforts) demands caution while interpreting the data, namely the proportion between continuity and innovation.
\end{abstract}

(c) 2013 Elsevier Ltd. All rights reserved.

\section{Introduction}

It is widely assumed that the integration in the Roman Empire implied severe changes for the conquered populations. A vast set of social, cultural and economical features are usually defined as Roman-type and are ascribed to the majority of the imperial territories, such as, among others, the existence of a complex system based on the complementarity between well structured and high productive rural areas and nearby cities, which presumed the existence of large villae owned by the upper classes; a significant weight of the Mediterranean triad (wheat, olive and vine) in agricultural strategies and local or regional economy; a market-orientation and monetization of agriculture and other productive practices, facilitated by territorial reorganization and technological and infrastructural development (Blázquez, 1967; Alarcão, 1988; Fabião, 1992).

Some of these features are easily identified in several Iberian regions, such as southern Spain and Portugal (Sáez Fernandez,

\footnotetext{
* Corresponding author. Tel.: +351967908314.

E-mail addresses: jptereso@gmail.com (J.P. Tereso), ramil.rego@gmail.com (P. Ramil-Rego), rubim.almeida@fc.up.pt (R. Almeida-da-Silva).
}

1987; Fabião, 1992). Still, one must question if uniform interpretative models should be used to approach all imperial areas and if that is not an artificial homogenization of a far more complex reality. The Iberian Peninsula is a vast and complex territory with diverse regions with different bioclimatic characteristics, different biological resources and soils. Additionally, in Iberia the Romans found several people with distinct cultural backgrounds. Thus, tentative characterization of agricultural practices in northwest Iberia during Roman times cannot be done by simply extending models from other regions where more data is available - e.g. southern Iberia.

Furthermore, characterizing the economical models of Romanized communities should not be done without integrating archaeobotanical information as well as data from other archaeometric approaches. It is not known if agronomical theories developed by reputed Roman agricultural writers - such as Cato and Varro (1913) and Columella (1960), the latter born in southern Spain were fully incorporated by local communities. In fact, acquiring reliable archaeobotanical and archaeological data is the best way to approach this question.

Syntheses of archaeobotanical data from northwest Iberia, including the territory of the conventus Bracaraugustanus have 
been produced before (Ramil Rego, 1993; Ramil Rego et al., 1996; Dopazo Martínez et al., 1996; Oliveira, 2000) but such studies are generic, outdated and data is usually interpreted with little chronological detail. Furthermore, recent work has been done by the authors of this article (Tereso, 2009a; Tereso et al., 2010a, 2011, and unpublished material), demanding a new, more insightful, approach.

\section{Characterization and history of the conventus Bracaraugustanus}

The study area corresponds to the conventus Bracaraugustanus. Its limits are not fully known but broadly it included northwest Portugal and southwest Galicia. The map in Fig. 1 shows the limits as defined by Tranoy (1981) and Alarcão (1988). Limits are merely hypothetic and only the southern boundary can be regarded as fully consistent. According to Tranoy (1981), mountain ranges of Suído and Testeiro and the valley of the river Sil would delimitate this conventus at north. The Atlantic Ocean constituted the western limit and to the East, the boundary was positioned in the mountains of Queixa, La Segundera, Nogueira and Bornes and the valley of the river Sabor. Alarcão (1988) suggests that the eastern limits, in the current Portuguese territory, would follow the river Tua and a line somewhere between the rivers Rabaçal and Tuela.

This area is characterized by the presence of several interior mountain ranges (the Galician-Portuguese or Galician-Minho Mountains), more or less with a NE-SW orientation, with altitudes above $1200 \mathrm{~m}$ (from North to South: Peneda with $1416 \mathrm{~m}$, Gerês/Xurés with 1548 m, Cabreira 1262 m, Alvão 1283 and Marão with $1415 \mathrm{~m}$ ). To the West of these mountains we find the coastal platform, cut by some of the main rivers (Minho, Cávado, Lima and Ave) in the region. To the South and Southeast the area is characterized by the alternation between plateaus and the valleys of the Douro hydrographic basin.

On climatic and biogeographic terms, the territory is almost completely placed in the Eurosiberian region (Costa et al., 1998; Rodríguez Guitián and Ramil-Rego, 2007, 2008). This region is characterized by the absence of a dry season, a reduced continentality and a long vegetative period that may extent to 8-9 months, favored by the proximity to the sea. In the rest of the year, at higher altitudes, abundant frost or snow imposes severe limitations to the development of vegetation. The southeastern part

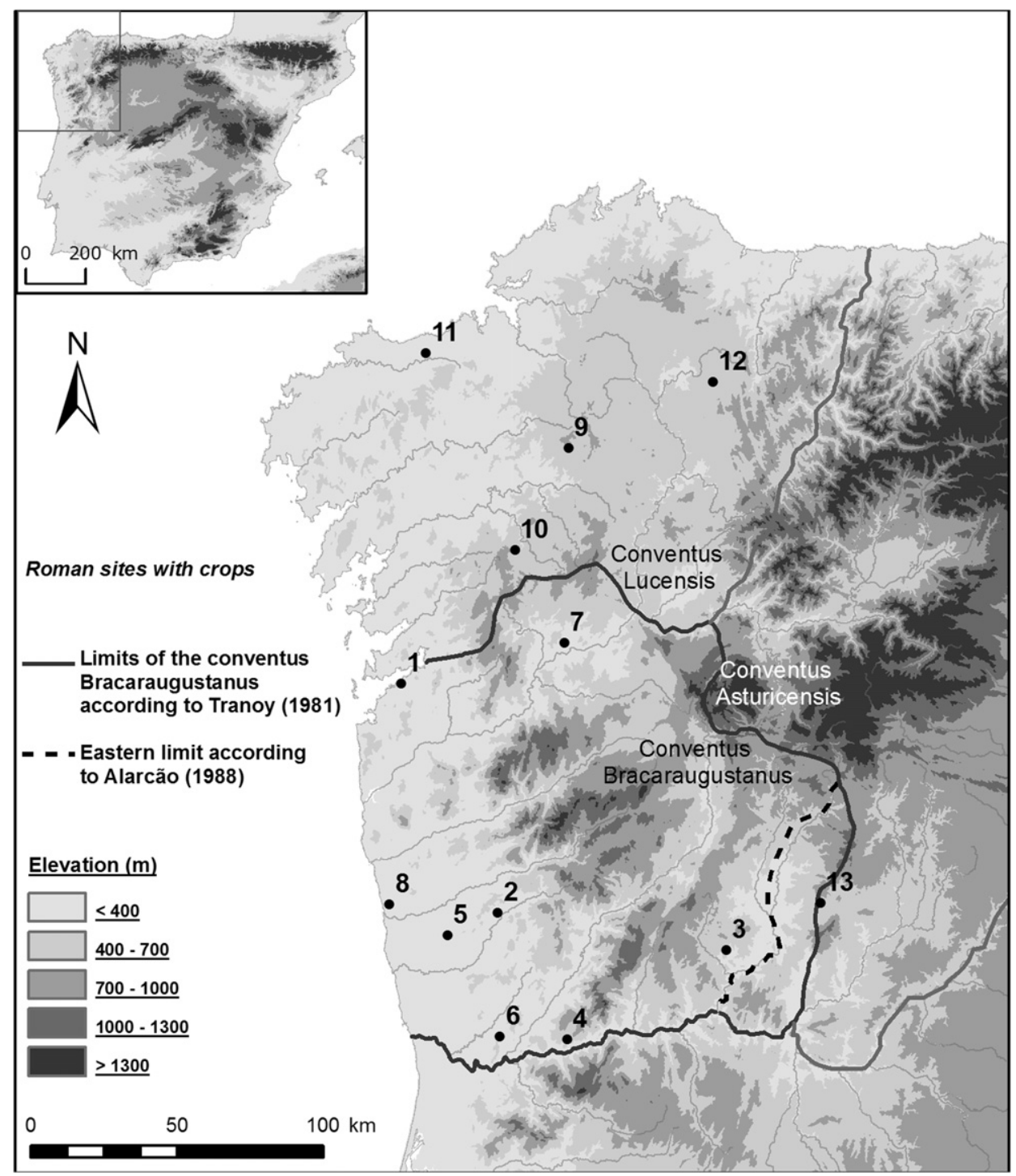

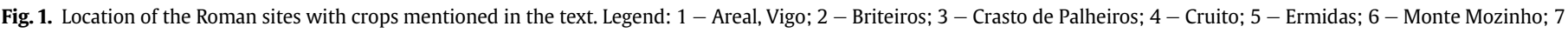
- San Cibrán de Las; 8 - São Lourenço; 9 - Castro Pedro; 10 - Montaz; 11 - Petón do Castro; 12 - Viladonga; 13 - Terronha de Pinhovelo. 
of the area is positioned in the Mediterranean biogeographic region (Costa et al., 1998), characterized by the existence of a dry season of at least three months and long periods of winter frost.

According to written sources, the first Roman incursions in the area here described took place in the second half of the 2nd century $\mathrm{BC}$, thus later than the Roman presence in southern and central areas of western Iberia, which dates back to the early 2nd century BC (Alarcão, 1988; Fabião, 1992). In fact, the first military expedition to this region occurred in $139 \mathrm{BC}$, during the war against the Lusitans, and was ordered by Q. Servilius Caepio. Later in 138-136 BC, after the pacification and subjugation of the territories south from the river Douro, the governor of Hispânia Ulterior, D. Iunius Brutus, organized a second expedition through the littoral, reaching the river Minho with little resistance (Alarcão, 1988; Santos Yanguas, 1988; Fabião, 1992; Morais, 2004). Although there is no evidence for the maintenance of any military force north from the Douro as a result, this expedition marks the beginning of the Roman presence in the area (Alarcão, 1988; Santos Yanguas, 1988; Fabião, 1992; Morais, 2004; Peña Santos, 2005).

In the first half of the 1st century BC, two other expeditions took place in the region, both aiming to obtain mineral resources and identify source areas. These were the peaceful expedition of 96-94 BC by P. Licinius Crassus and that of C. Iulius Caesar in 61$60 \mathrm{BC}$ which passed the river Minho and reached Brigantium (A Coruña) (Santos Yanguas, 1988; Fabião, 1992; Morais, 2004). It is not clear whether the Romans got effective control over the region after these incursions (for different opinions see Alarcão, 1992; Peña Santos, 2005).

The Cantabrian Wars (29-19 BC) by which Augustus finished the occupation of all Iberia, took place mostly outside the callaican area (Santos Yanguas, 1988; Martins, 1990; Morais, 2004; Peña Santos, 2005). Still, this direct intervention of the emperor was the turning point for western and northern Iberia, after which instability and rebellions became occasional (Alarcão, 1988; Carvalho, 2008).

It was in Augustus reign that the administrative efforts began in the northwest Iberia and particularly in what would be the conventus Bracaraugustanus (Morais, 2004). This emperor founded the cities of Bracara Augusta (Braga), Lucus Augusti (Lugo) and Asturica Augusta (Astorga) in the late 1st century BC. Each would become the head of a conventus. The chronology of creation of the conventus is not consensual but may have happened already in Augustus reign, early in the 1st century $\mathrm{AD}$ (Morais, 2004).

The northern Portugal and the area of Bracara Augusta were first included in the Province of Lusitania but soon became part of the Province of Tarraconensis (Alarcão, 1988; Fabião, 1992; Carvalho, 2008). The consolidation of the Roman administration occurred in the Flavian dynasty. In this period, the urban centers in northwest Iberia were renewed, new cities were founded and the territorial connection was enhanced (Carvalho, 2008). A progressive abandonment of the characteristic Iron Age hillforts - locally known as Castros - began already in the early 1st century AD but this process was hastened in the end of that same century and the beginning of the following, i.e., the Flavian period. Meanwhile, Roman rural settlements such as villae and small farms appeared in the region, mostly connected to the main roads and the cities (Morais, 2004; Carvalho, 2008). Although it is difficult to characterize how the regional models for territorial exploitation and organization changed, the establishment of these new settlements implied severe changes at the property regime (Carvalho, 2008). Changes were surely not uniform in all the conventus territory and those typical Roman settlements are only common in the western areas, where the influence of the urban center, Bracara Augusta, was more evident. In the eastern regions, the establishment of unfortified settlements inhabited by several families - villages - some small, other with several hectares (Alarcão, 1998; Sande Lemos, 1993), suggests the territory was structured differently. At the same time, all over the conventus, many hillforts continued to be inhabited throughout all the Roman period, most of them losing much of their population. The territory was mainly rural.

Nevertheless, the 1 st century AD was a phase of economical and structural development in the city and conventus of Bracara Augusta, one which was not clearly disrupted in the following century (Morais, 2004). The city of Bracara Augusta acted not only as a political center, it had an important role in importing and redistributing goods in the region and it was an important production center for several kinds of utilities. The rural areas in the surroundings of the city were surely structured regarding their role as suppliers but, at the same time, the rural character of the region conditioned the city dynamics (Morais, 2004).

The 3rd century was a period of disturbance in the empire but it is not clear the real impact the political and economical crises had in the region. Later in this century, Bracara Augusta would even become the head of a new province - Callaecia (Alarcão, 1988; Fabião, 1992; Morais, 2004). In the beginning of the 5th century (409-411 d.C.), during the internal wars between pretenders to the imperial throne, Vandals, Suebi and Alans entered the Iberian Peninsula and ended up establishing themselves in northwest Iberia (Alarcão, 1988; Fabião, 1993).

\section{Materials and methods}

A major revision of carpological data from conventus Bracaraugustanus was carried out, but revision was extended to other areas northwestern areas of the Province of Tarraconensis, to provide us with a proper regional context and position our study area in a broader context, making it possible to compare data and analyze tendencies in a more accurate way. Furthermore, new unpublished material was also included.

Critical and careful evaluation of published data was done and only those archaeobotanical materials with reliable references to context and chronology were considered. As such, some published data from several archaeological sites was not included in this study: A Graña, Boimorto and Castro de Vigo (Téllez et al., 1990), as well as Penices (Buxó quoted in Figueiral, 1990; Oliveira, 2000) and Cividade de Terroso (Gomes and Carneiro, 2005), for not providing reliable data regarding the chronological insertion of the remains; Baran, Castro de Fréan and Franqueira (López Cuevillas, 1953), as well as Corredoiras (Dopazo Martínez et al., 1996) whose chronological insertion provided is too vague (Bronze Age, Iron Age or Roman Period) and derives only from the fact that such sites are hillforts.

Data from Noville, a Roman villa in northern Galicia, were not taken into consideration. Ineffective storage of the archaeological soil samples misled archaeobotanists to consider some samples to have been recovered in Noville when they were in fact recovered in a Pre-Roman archaeological site in the region. Therefore, data obtained by Dopazo Martínez (1996) and referred by several authors thereafter (e.g. Dopazo Martínez et al., 1996; Ramil Rego et al., 1996; Ramil Rego and Fernández Rodríguez, 1999; Oliveira, 2000; Teira Brión, 2010) are not from Noville.

Carpological data from As Laias (Cenlle, Spain) (CSIC-1402$2033 \pm 26 \mathrm{BP}, 155 \mathrm{cal} \mathrm{BC}-49$ cal AD at $2 \sigma$; radiocarbon date in Carrión Marco, 2003, carpological data unpublished) and S. João de Rei III (Póvoa de Lanhoso) (CSIC-1148-2006 \pm 26 BP, 83 cal BC 63 cal AD at 2 $\sigma$; Bettencourt, 1999; Oliveira, 2000) were mentioned in the text, for comparison, but not included in the tables since they were not considered to be Roman. In some cases, it is difficult to understand if contexts chronologically attributed to the turn of the Era are Roman or Pre-Roman, as a result of the wide interval of the 
radiocarbon dates of this phase, the imprecise chronology of the Roman conquest and the (cultural and archaeological) continuity between the Iron Age and the first Roman phases. This suggests that such division is somehow artificial, making it necessary to regard each context individually. Both the structure of the settlements and the archaeological artifacts recovered at As Laias (Álvarez González and López González, 2000 and personal communication) and S. João de Rei III (Bettencourt, 1999) show no sign of a Roman influence.

In addition, this study includes references to unpublished material from San Cibran de Las (Ourense, Spain), Briteiros (Guimarães, Portugal) and Monte Mozinho (Penafiel).

Here we present a synopsis of the Roman contexts where samples were retrieved as well as the basic information regarding the methods applied in each site mentioned in Tables 1 and 2:

Briteiros (Guimarães, Portugal) - Strategic sampling and flotation took place during three archaeological campaigns (20062008) directed by F. Sande Lemos, M. Manuela Martins and Gonçalo Cruz. 47 samples, from $0.5 \mathrm{~kg}$ to $15 \mathrm{~kg}$, were recovered, covering all major deposits from three different areas: a domestic compound, a nearby platform and a street area, all in the uppermost platform of the hillfort. Remains come from dispersed contexts, most of them from the Iron Age but some few date from the beginning of the Roman presence in the area. The latter are considered in this synthesis. There is no radiocarbon date for these contexts. Citânia de Briteiros was inhabited from the Late Bronze Age to the 2nd century AD (Lemos and Cruz, 2010).
Crasto de Palheiros (Murça, Portugal) - Systematic sampling took place in this site but not all samples were yet studied. Plant remains are abundant in Chalcolithic and Iron Age levels. M. J. Sanches, based on abundant radiocarbon dates and archaeological artifacts, suggests the fire which preceded the abandonment of the site, at the end of its Phase III-1, happened in the end of the 1st century AD (Sanches, 2008). From this moment of abandonment with great concentration of charred plant remains, 10 samples with carpological remains were studied; volumes vary from $1 \mathrm{~L}$ to $5 \mathrm{~L}$ (Figueiral, 2008).

Cruito (Baião, Portugal) - Neither published material (Silva, 1988a) or unpublished reports (by Pinto da Silva, courtesy of A. Pereira) mention any sampling strategy or the volume of samples and neither a general characterization of the contexts where they were recovered. Stratigraphy suggests a single moment of occupation and archaeological artifacts, together with a radiocarbon date, suggest it took place in the turn of the Era, most likely in the 1st century AD (Pereira and González, 1988).

Ermidas (Vila Nova de Famalicão, Portugal) - Carpological remains were found in seventeen samples from the 1st century AD, recovered throughout the site. The volumes of these samples and sampling strategy are not referred in any publication (Queiroga, 1992; Oliveira et al., 1991).

Monte Mozinho (Penafiel, Portugal) - Preliminary data from few samples was already published (Tereso et al., 2010b) but data from this synthesis takes in consideration other, yet unpublished material studied by the authors. Abundant soil samples were

Table 1

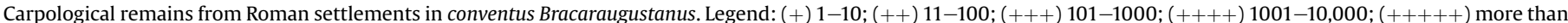

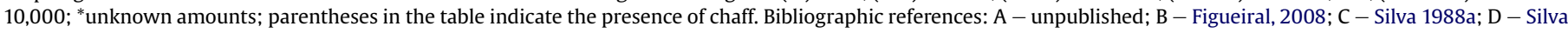
1988b; E - Queiroga 1992; F - Tereso et al., 2010b; G - Tereso et al., 2010a.

\begin{tabular}{|c|c|c|c|c|c|c|c|}
\hline \multirow[t]{2}{*}{ Site } & \multicolumn{7}{|c|}{ Conventus Bracaraugustanus } \\
\hline & San Cibran de Las & Briteiros & Crasto de Palheiros & Cruito & Ermidas & Monte Mozinho & São Lourenço \\
\hline Chronology & 1st BC/1st AD & 1 st $B C / 1$ st $A D$ & $1 \mathrm{st} \mathrm{AD}$ & 1 st $\mathrm{AD}$ & $1 \mathrm{st} A \mathrm{AD}$ & 3rd/4th & 4th/5th \\
\hline \multicolumn{8}{|l|}{ Cereals } \\
\hline Avena & & + & & & & +++ & \\
\hline cf. Avena & & & & + & & & \\
\hline Hordeum & & & +++ & & & & \\
\hline Hordeum vulgare var. nudum & & & & + & & & \\
\hline Hordeum vulgare subsp. vulgare & ++ & + & $(++++)$ & & + & + & \\
\hline Panicum miliaceum & & + & +++++ & & ++++ & +++ & ++ \\
\hline Panicum/Setaria & & + & +++ & & +++ & +++ & ++ \\
\hline Secale cereale & & & & ++ & & $(++++)$ & \\
\hline Setaria italica & & & & & & +++ & ++ \\
\hline Setaria & & & & & +++ & & \\
\hline Triticum aestivum & & & & & & $(+++)$ & \\
\hline Triticum aestivum/durum & & + & & $*$ & +++ & +++ & + \\
\hline Triticum “stubby grains” & & & & * & & + & \\
\hline Triticum dicoccum/spelta & & & +++++ & & & $(+)$ & \\
\hline Triticum turgidum subsp. dicoccum & & + & $(*)$ & $*$ & & & \\
\hline Triticum aestivum subsp. spelta & & & $(*)$ & & & & \\
\hline Triticum & & ++ & ++++ & & + & + & + \\
\hline Cereals - undetermined & & & $*$ & & + & +++ & \\
\hline \multicolumn{8}{|l|}{ Pulses } \\
\hline Pisum sativum & + & & & & & & \\
\hline Vicia faba & + & & +++ & + & & & \\
\hline Vicia & & + & & & & ++ & \\
\hline \multicolumn{8}{|l|}{ Fruits } \\
\hline Arbutus unedo & & & $*$ & & & & \\
\hline Olea europaea & & & & & + & & \\
\hline Pinus pinea & & & + & & & & \\
\hline Prunus & & & & + & & & \\
\hline \multicolumn{8}{|l|}{ Pyrus communis } \\
\hline Quercus (cupule) & & & & + & & & \\
\hline Quercus (cotyledon) & & & & $*$ & & + & \\
\hline Rubus & & + & & & ++ & + & \\
\hline Vitis vinifera & & ++ & & + & & + & \\
\hline References & A & A & B & C, D & $\mathrm{E}$ & $\mathrm{F}, \mathrm{A}$ & G \\
\hline
\end{tabular}


Table 2

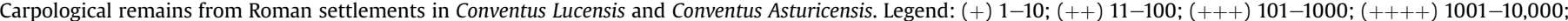

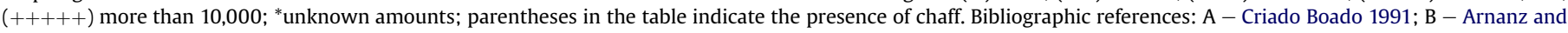
Chamorro 1990; C - Dopazo Martínez 1996; D - Dopazo Martínez et al., 1996; E - Ramil Rego et al., 1996; F - Tereso 2007a; G - Tereso, 2009a.

\begin{tabular}{|c|c|c|c|c|c|}
\hline \multirow[t]{2}{*}{ Site } & \multicolumn{4}{|c|}{ Conventus Lucensis } & \multirow{2}{*}{$\frac{\text { C. Asturicensis }}{\text { Terronha de Pinhovelo }}$} \\
\hline & Castro Pedro & Montaz & Petón do Castro & Viladonga & \\
\hline Chronology & 1st BC/1st AD & 1st AD & 2nd & & 4 th $/ 5$ th \\
\hline \multicolumn{6}{|l|}{ Cereals } \\
\hline Avena & & & ++ & * & \\
\hline Hordeum & & & ++ & & \\
\hline Hordeum vulgare subsp. vulgare & & & & & +++ \\
\hline Panicum miliaceum & & * & & & ++ \\
\hline Panicum/Setaria & & & +++ & & \\
\hline Setaria italica & & & & & + \\
\hline Triticum aestivum/durum & & & & & +++ \\
\hline Triticum “stubby grains” & & & & & +++ \\
\hline Triticum dicoccum/spelta & & & & & ++ \\
\hline Triticum turgidum subsp. dicoccum & & & & & $(+++)$ \\
\hline Triticum monococcum & & & & & $(++)$ \\
\hline Triticum aestivum subsp. spelta & $(+)$ & & & & $(+++)$ \\
\hline Triticum & & & +++++ & * & ++++ \\
\hline Cereals - undetermined & & & & & ++ \\
\hline \multicolumn{6}{|l|}{ Pulses } \\
\hline Pisum sativum & & & ++ & & \\
\hline Vicia faba & & & ++++ & & +++ \\
\hline \multicolumn{6}{|l|}{ Other crops } \\
\hline Linum & & & ++++ & & \\
\hline \multicolumn{6}{|l|}{ Fruits } \\
\hline Pyrus communis & & & & $*$ & \\
\hline Quercus (cotyledon) & & & & $*$ & + \\
\hline References & A & B & $\mathrm{C}$ & $\mathrm{D}, \mathrm{E}$ & $\mathrm{F}, \mathrm{G}$ \\
\hline
\end{tabular}

retrieved in the excavations coordinated by Teresa Pires de Carvalho, in 2008 and 2009, varying from $1 \mathrm{~L}$ to $23 \mathrm{~L}$, according to the type of context and botanic richness, and covering all major units of stratification. They were recovered in two compartments of a compound, from levels dated by radiocarbon to the 3rd century or the first half of the 4th century $\mathrm{AD}$. In one compartment, remains were restricted to a storage facility while in the other, storage facilities provided few remains but these were abundant throughout the compartment in what was interpreted as remains of fodder. Monte Mozinho is a hillfort founded in Augustus time, occupied until the 5th-6th century (Soeiro, 1998; Carvalho and Queiroga, 2005).

San Cibrán de Las (Ourense, Spain) - Sporadic carpological material was handpicked during the 2003 excavations at the interior of a patio of a domestic compound, a Roman context dating back to the turn of the Era (Y. Álvarez González personal communication). There is no radiocarbon date for this context. San Cibran de Las was inhabited from the 2nd century BC to the 2nd century AD (Álvarez González et al., 2009).

São Lourenço (Esposende, Portugal) - Carpological study at São Lourenço was restricted to twelve small test samples (c. 2 L) recovered in dispersed deposits and a hearth in two test pits, near the main defensive wall (Tereso et al., 2010a). Contexts were attributed to the Late Roman Empire (4th or 5th centuries) by the presence of ceramics and coins.

Castro Pedro (Melide, Spain) - Most remains come from a storage facility within the site's defensive wall. They date back to the last level of occupation of the settlement, from the turn of the Era, according to the archaeological artifacts recovered (Criado Boado, 1991). There is no data available regarding the volume of sediment studied.

Montaz (Silleda, Spain) - There is no reference regarding the amount and volume of samples that were recovered (Arnanz and Chamorro, 1990 unpublished, courtesy of X. Carballo Arceo). Despite diverse remains were recovered from Iron Age levels, those from Roman contexts are more restricted and are attributed to the 1 st century AD.

Petón do Castro (Bergantiños, Spain) - Fifteen samples were taken from a storage facility. Their volume is not known neither whether they correspond to the total amount of sediment taken from the structure (Dopazo Martínez, 1996). Petón do Castro is a hillfort with a single archaeological level, from the 2nd century AD. There is no radiocarbon date available.

Terronha de Pinhovelo (Macedo de Cavaleiros, Portugal) Systematic sampling occurred in levels from the 4th or 5th century, covering dispersed sediments, a storage facility and four hearths (Tereso, 2007a, 2008a, 2009a). The sample size varied from 1 to $12 \mathrm{~L}$. Sediment from the fireplaces was fully recovered (values in $\mathrm{kg}$ : $9 ; 1 ; 84 ; 52 ; 66 ; 29$ and 4.95 ) for subsequent subsampling. Furthermore, some plant remains were handpicked during the field work. Terronha de Pinhovelo is a settlement occupied during the Iron Age and throughout the Roman period (Barranhão and Tereso, 2006; Silva, 2007; Tereso, 2008a; 2009a). There is no radiocarbon date available.

Viladonga (Castro de Rei, Spain) - There is almost no data referring to the contexts and magnitude of the sampling done in this settlement. Available information is limited to the first 4 samples that were studied, all weighting $0.8 \mathrm{~kg}$, having been recovered from a paleosol in a single platform of the settlement (Ramil Rego, 1993). Reference to chronology is vague.

In order to synthesize the data from the different sites in a way that would allow comparisons, the quantification of the archaeobotanical material was done in intervals, referring to the number of fruits/seeds recovered: 1-10, 11-100, 101-1000, 1001-10,000, more than 10,000 . In some cases quantification is impossible due to lack or data in the bibliography. Simple quantification in intervals is preferred to a presence/absence system which could overestimate occasional remains. At the same time, the use of intervals and correspondent symbols (see caption in Tables 1 and 2) is preferred to discrete values since it allows a better visual perception of 
results in tables, making comparisons easier, despite some homogenization may occur.

Regarding the crops mentioned in the bibliography, the revision of data included a revision of nomenclature. This way, the morphological type Triticum compactum used in the archaeobotanical study of Terronha de Pinhovelo (Tereso, 2007a, 2007b, 2008a, 2009a, 2009b) and the "globiform wheat" and Triticum parvicoccum, used by Pinto da Silva in the study of Cruito (Pinto da Silva, unpublished report of 1987, provided by António da Silva Pereira) are here designated as Triticum "stubby grains", following S. Jacomet (2006). This refers to roundish grains, shorter than those of Triticum aestivum/durum, and can include three subspecies that cannot be distinguishable from their grain morphology: T. aestivum subsp. compactum, T. aestivum subsp. sphaeorococcum and Triticum turgidum subsp. parvicoccum. Underdeveloped grains of other naked wheat species (included in the morphological type T. aestivum/durum) can present the same morphological features.

The T. aestivum/durum type includes T. aestivum subsp. aestivum, T. turgidum subsp. durum, and T. turgidum subsp. turgidum (Buxó, 1997). Regarding naked wheat, only chaff-based identifications were considered at species level.

Furthermore, remains of Brassica/Sinapis from Petón do Castro (Dopazo Martínez, 1996) and Viladonga (Dopazo Martínez et al., 1996) were not included in this synthesis since a revision of the Brassica/Sinapis seeds from other contexts in the region allowed us to question the criteria used for such identification, although the true nature of such remains is not yet known.

\section{Results and discussion}

\subsection{Crops in conventus Bracaraugustanus according to archaeobotanical data}

It is clear by the list of sites with carpological remains (see Table 1) that they correspond, with only one exception, to hillforts. Much of the archaeology of northwest Iberia was directed to the study of this kind of sites, justifying this scenario. Most of these settlements were built during the Iron Age but, as mentioned before, continued to be inhabited in the beginning of the Roman period. Many were abandoned during the 2nd century AD but others remained inhabited. This way, it is not surprising that most of the carpological data come from contexts covering a time-span from the turn of the Era to the 2nd century AD.

The data from carpological remains recovered in Roman levels from hillforts located in the conventus Bracaraugustanus demonstrates there is a clear predominance of cereals, in particular naked wheat (T. aestivum/durum), Panicum miliaceum and Hordeum vulgare subsp. vulgare. The presence of hulled wheat - mostly T. turgidum subsp. dicoccum and T. aestivum subsp. spelta - and Avena is also important. Since only caryopses were found, it is not possible to distinguish different species of oat (see Jacomet, 2006). Other cereals are found in fewer sites: H. vulgare var. nudum, Setaria italica and Secale cereale.

When adding sites that date back to the transition from the Iron Age to the Roman period, like As Laias and S. João de Rei, as well as data from settlements of other conventus in northwest Iberia (see Table 2), the scenario remains the same. In As Laias, the main crop was spelt, followed by $P$. miliaceum but oat and hulled barley were also present (Tereso, unpublished). The relevance of hulled wheats is also clear in Castro Pedro (Criado Boado, 1991), in the 4th or 5th centuries levels of Terronha de Pinhovelo (Tereso, 2009a) and in the unfortified settlement of Agro de Ouzande (Silleda), near the eventual northern limit of the studied conventus. In this latter, microbotanical evidence suggests the grinding of Triticum dicoccum, together with naked wheat, P. miliaceum and Quercus acorns
(Juan Tresserras and Matamala, 2002). As for oat, it was recovered also in Petón do Castro and Viladonga (Dopazo Martínez et al., 1996).

Regarding garden crops, Vicia faba is the most relevant crop, being the only with a significant presence in the Roman archaeobotanical assemblages of the conventus Bracaraugustanus. It is present also in As Laias (unpublished) and S. João de Rei (Oliveira, 2000) and in sites of the other conventus. Finds of Pisum sativum are restricted to a single seed found in San Cibran de Las (San Amaro). Outside this conventus, it was recovered in Petón do Castro (Dopazo Martínez et al., 1996). In Agro de Ouzande, several evidence of Brassicaceae was found in one vessel (sclereids, epidermal and parenchymatous tissue and sterols) and one storage facility (seed coats) (Juan Tresserras and Matamala, 2002). Seeds from vetch - Vicia sativa/angustifolia (Vicia angustifolia $=V$. sativa subsp. nigra) were found in Monte Mozinho. This species could have been cultivated for fodder, as stated by Columella (Res Rustica Book II, VII, 1). Still, its presence among by-products (chaff and weeds) of crops, together with its known ecological amplitude (Pinho and Pinho, 1998; Romero Zarco, 1999) makes it possible that it simply bordered agricultural fields or was, itself, a weed. The concentration of by-products in one compartment, in Monte Mozinho, led to the conclusion that they were used as fodder (Tereso unpublished). This means that plant husbandry and animal husbandry were intertwined and were both a part of the same complex system. Such reality was already documented elsewhere in a Pre-Roman Iberian context (Pérez Jordà, 2004).

The only Roman assemblage in northwest Iberia with Linum is Petón do Castro (Dopazo Martínez, 1996) making it difficult to understand the relevance of such crop in the region. Its cultivation began in the Chalcolithic - Buraco da Pala (Mirandela) (Ramil Rego and Aíra Rodríguez, 1993) and Bitarados (Esposende) (Bettencourt et al., 2007), but it was not found in any Bronze Age or Iron Age site. Still, Pliny mentions the flax produced by the Zoelae (Pliny, Nat. Hist., 19, 1):" Recently [the flax] from the Zoelae came from Spain to Italy. It is very good to manufacture nets". The Zoelae (and the Civitas Zoelarum) are known to have been part of the conventus asturicensis (Tereso, 2008a, 2008b). They bordered the conventus Bracaraugustanus in Eastern Portugal and in the Spanish province of Zamora (from the sites mentioned, only Terronha de Pinhovelo is likely to have been a Zoelae settlement). Despite Pliny words, it is difficult to address the economical significance of flax in the region since the same author points out other regions in Iberia and the Mediterranean producing flax, some of which (e.g. Egypt), closer and with great commercial activities with Rome (see discussion at Tereso, 2008b).

It is difficult to compare data with other regions in northern Iberia since only in Catalonia abundant archaeobotanical studies have been carried out (Buxó, 2005). In Atlantic areas few archaeobotanical data is available. Differences between the conventus Bracaraugustanus and Catalonia are expected due to several geographic and climatic aspects which distinguish these two regions but also because the latter was one of the first areas influenced by Mediterranean trends - Greek, Phoenician and Roman (Buxó, 2008). The main difference between the archaeobotanical assemblages of these regions are the higher diversity of pulses and fruits identified in the northeast and the little relevance of millets, which became residual crops (Buxó, 2005). In the northwest Iberia, millets, mainly P. miliaceum, continues to be a very important crop in the region, as it was in the Iron Age. Oat was probably a more important crop in the northwest than in Catalonia. Still, other features of the agriculture of both regions are similar: the predominance of T. aestivum/durum and hulled barley; the residual presence of naked barley and Triticum "stubby grains". Emmer was a relevant crop in Catalonia but spelt is not recorded. Rye is more 
frequent in Catalonia, especially in late dates, in transition toward the Middle Ages.

Regarding the presence of fruits and fruit trees (wild or domestic) in Roman sites in northwest Iberia, the data available is very sparse. The only site in all northwest Iberia with significant presence of cultivated fruits is Areal, a salt pan and an ancient port area in Vigo (Martín Seijo and Teira Brión, 2010; Teira Brión, 2010) but the available data regarding the archaeological context is still sparse making it difficult to evaluate its carpological assemblage with no parallel in the region.

Wild fruits are not common in Roman sites from the conventus Bracaraugustanus. Only Rubus seeds and Quercus cotyledons were retrieved in a significant number of sites. Acorns were found in other sites with no crops, thus not present in Tables 1 and 2, such as the 1st century AD level of S. João de Rei (Póvoa de Lanhoso) (Oliveira, 2000). The consumption of acorns was recurrent in Iron Age settlements in northwest Iberia (Ramil Rego, 1993; Dopazo Martínez et al., 1996; Tereso, 2012), thus it is not surprising that such habit continued in Roman times.

\subsection{Olive oil and wine in the conventus Bracaraugustanus}

Fruits from Olea europaea were recovered in the Roman levels of Ermidas (Vila Nova de Famalicão) (Queiroga, 1992), still they are few. In northeast Iberia, near the Mediterranean, the presence of olive stones in archaeological sites is more conspicuous (Buxó, 2005). Furthermore, in the area of the conventus Bracaraugustanus, the presence of olive stones in Pre-Roman contexts is confirmed. In fact, the recovery of such remains in the Early Neolithic settlement of Bolada (Celorico de Basto) (Sampaio and Carvalho, 2002) and in the Chalcolithic levels of Crasto de Palheiros (Murça) (Figueiral, 2008) tallies palynological data assuring wild olive is native to the region. However it was not a predominant species, being more prone to expand in Mediterranean bioclimatic regions.

Still, the almost absence of carpological remains of olive in the study area has little informative value since many factors can lead to their underrepresentation (e.g. a preservation bias because the consumption as a whole fruit or the processes to obtain olive oil do not imply the use of fire) (Tereso, 2008b). Nevertheless, palynological sequences in northwest Iberia do not show clear signs of an increase in Olea pollen curve in Roman times (Muñoz Sobrino et al., 1997; Ramil Rego et al., 1998), as one would expect if an economically relevant local production existed. However, caution is needed, due to the lack of palynological data from the southernmost areas which are, nowadays, more prone for the cultivation of olive, i.e. near the river Douro and in the northeast Portugal.

Strabo says, referring to the mountain people from northern regions, at the time of the Cantabrian wars by which Augustus finished the conquest of Iberia: "Instead of oil they use butter" (Strabo, 1992, Geography, Book III, 3, 7). Caution is needed while interpreting Strabo writings since they are ideologically conditioned (Fabião, 1992), but it is possible that these words were true. In fact, Ruis Morais $(1997 / 1998,2004)$ mentions a notorious scarcity of Roman oil amphorae, which, together with the palynological data, sparse archaeobotanical data and the words of Strabo, suggests animal fat was preferred to olive oil at least in the Iron Age and Early Roman Empire.

As for other archaeological data, there are references to two eventual structures related to olive oil extraction. In Fonte do Milho (Peso da Régua), a villa next to the river Douro, remains of two molae oleariae were found, but its chronology is uncertain. The site was founded in the turn of the Era, but the mentioned structures may be ascribed to the Late Roman Empire (Morais, 1997-98; Almeida, 2006). An eventual olive mill was found also in the coastal villa of Fontão (Matosinhos) (Brun, 1997; Morais, 2004) but the data available regarding this site is clearly insufficient.

Pips from Vitis vinifera are not abundant in the archaeobotanical assemblages but they were recovered in several sites, suggesting they were not uncommon, since a preservation bias can theoretically lead to an underrepresentation of this species in archaeological sites (Tereso, 2008b). They were recovered in Briteiros (Guimarães), Cruito (Baião) and Monte Mozinho (Penafiel). Briteiros is the settlement where they are more frequent and even here only 20 pips were found in Roman levels, together with 14 in Iron Age levels (unpublished).

Interestingly, in all northwest Iberia, grape pips and olive stones were only recovered in sites from the conventus bracaraugustanus. This is the most southern area in northwest Iberia - in the southern regions of the conventus asturicensis (northeast Portugal) few archaeological and archaeobotanical work has been done until now.

Climatic reasons may justify the exclusive presence of grapes in this southern area, although the social background of local communities could have been a significant factor. Grape pips were found in Iron Age and even in Chalcolithic and Late Bronze Age sites in northern Portugal (Tereso et al., 2011) but none was found in northwest Spain. V. vinifera is a native species to the Mediterranean and the early remains from the Chalcolithic levels at Buraco da Pala (Ramil Rego and Aira Rodríguez, 1993) suggests its gathering. Iron Age remains may be a result of gathering, trade or cultivation. It is clear that vine could be more easily cultivated in the southernmost regions but, at the same time, these were the more developed regions during the Iron Age and those with more direct and influencing contacts with the Mediterranean world (González-Ruibal, 2003). Thus it is possible that in these southern regions the habit of drinking wine was more established before the Roman conquest, than in the north.

However, the remains of grapes, namely the pips, are not direct evidence of wine production or consumption. Ultimately, they are evidences of the presence and consumption of grapes. In our study area, evidences for wine consumption in Roman times are restricted to amphorae. These are common in the beginning of the Roman period in this region and testify for the great relevance of wine imports from several origins, mostly Baetica (southern Spain), in the end of the 1 st century $\mathrm{BC}$ and throughout the 1 st century $\mathrm{AD}$ (Morais, $1997 / 1998,2004)$. The relevance of such imports is used to suggest the absence of wine production in the region and, consequently, the decrease in wine imports in the 2 nd century AD should mean that wine production was already well established in the region by that time (Morais, 1997/1998, 2004). Still, such assumption needs to be verified by other sources, since trading routes could have been altered and other vessels could have been used.

The interpretation of some feature interfaces in Rúa Ferreiría, in the city of Pontevedra (northwest Spain) (Teira Brión, 2010, Fig. 4) as structures related with vine cultivation is questionable and should be supported by archaeometric data.

Regarding the eventual presence of wine presses in the region, these were mostly recorded in the southernmost area, near the river Douro. Most of these structures lack the proper archaeological context and their chronology is uncertain (Coixão, 2002; Sousa et al., 2006). Still, structural evidences of a wine press were found inside the villa of Rumansil (Vila Nova de Foz), near the conventus baracargustanus, south from the river Douro, dating back to the 3rd century AD. Grape pips were also found (Coixão and Silvino, 2006). In the Late imperial villa of Fontão do Milho (Peso da Régua) near the river Douro, a cella vinaria was recorded (Almeida, 2006). In Monte Mozinho a possible wine or olive press was found near the center of the settlement (Soeiro, 1998). 
Several structures have been mentioned for other sites in the Douro region and others located far to the north (Almeida, 1996). Thus, wine production in this conventus was likely to have occurred, mostly in the southern areas and probably in late periods, but it is not possible to know whether it was economically relevant.

The discussion regarding the production of wine and oil should be improved in the future by acquiring data from structures or artifacts through chemical analyses and other techniques. Different approaches were carried out successfully in Eastern Mediterranean and Near Eastern sites (e.g. Kimpe et al., 2001; Pollard et al., 2007; Barnard et al., 2011).

\subsection{Signs of continuity and change}

By the time of the first Roman incursions in the region and until the full dominance of the region by the end of the 1st century BC, indigenous communities already had well developed agricultural strategies based on the complementarity of different crops (Tereso, 2012). In the archaeobotanical record there is a predominance of oat, hulled barley, broomcorn millet and emmer; significant presences of spelt, naked wheat (T. aestivum/durum) and faba bean and minor presences of foxtail millet, einkorn, naked barley and peas. Overall, major crops were not soil demanding and were resistant to harsh climatic conditions. In this scope, the high relevance of hulled wheats in the carpological records of the region is noticed (Tereso, 2012).

Thus, contrary to what Strabo wrote (Strabo, 1992, Geography, Book III, 3, 7), the Romans did not encounter societies which were almost unproductive, dependant on acorns to feed. However, despite having interesting data for Iron Age and Roman northwest Iberia, it is difficult to fully characterize the impact of Romanization in the agricultural strategies of people in the area of the conventus Bracaraugustanus and in all northwest Iberia. As we have pointed out, data obtained derive mainly from indigenous-type of settlements, the hillforts, and no data is available for Roman-type establishments.

Overall, there is a general sense of continuity regarding the Iron Age in northwest Iberia. The predominant crops are the same: naked (T. aestivum/durum) and hulled wheat (T. turgidum subsp. dicoccum and $T$. aestivum subsp. spelta), hulled barley ( $H$. vulgare subsp. vulgare), broomcorn millet (P. miliaceum), oat (Avena) and faba bean $(V . f a b a)$. Thus, it is likely that agricultural systems did not change much, at least for those communities who continued to live in the hillforts.

The maintenance of hulled wheats - emmer and spelt - as relevant crops is not surprising, even considering the new political dominance. Columella stated that no farmer should rely on only one crop but rather should adjust the set of crops to the range of fields within the property: "these kinds of wheat and emmer should be kept by farmers for this reason, that seldom is any land so situated that we can content ourselves with one kind of seed" (Collumela, Res Rustica, Book 2, 6, 4).

This rationality may justify the spread of rye throughout the Roman Empire, despite the prejudice toward its taste demonstrated by Pliny, who says "It is the worst kind of bread and it is only useful to prevent famine" (Plin. Nat. Hist. 18. 16). Still, Pliny, itself, adds that "It grows in any land, yields a hundred-fold and [its straw] is employed also as manure". This justifies the cultivation of rye, regardless of its (subjective) unappreciated taste. It grows where other cereals do not, being, thus, extremely useful for communities or households to maintain their resilience. In this sense, the introduction of rye on northwest Iberia met the objectives of subsistence in an area with significant topographic and edaphic constraints which had already limited agricultural choices during the Iron Age. Its role was similar to that of the hulled wheats.
Rye was recovered in two sites, separated from each other by only $23 \mathrm{~km}$, Monte Mozinho and Cruito (Fig. 1). Interestingly, despite being indigenous-type of settlements, Cruito and Monte Mozinho were founded in Roman times, contrary to all other hillforts with crops in conventus Bracaraugustanus. Up to now, it is not possible to know if there is any relation between this chronological peculiarity and the cultivation and consumption of rye.

In the settlement of Monte Mozinho, chaff and grains of rye were recovered in abundance. Some grains were directly radiocarbon dated to the $3 \mathrm{rd}$ - beginning of the 4 th centuries AD (Tereso unpublished). At Cruito data is more problematic since it has a much earlier chronology. A radiocarbon date obtained on charcoal provided a wide interval covering the transition of the Era (Figueiral, 1990; Oliveira, 2000) but archaeological materials led to the consideration of a 1 st century AD chronology (Pereira and González, 1988). The site provided a simple stratigraphy with only one clear occupation phase, suggesting later intrusions to be improbable.

However, the presence of rye in only two sites from this conventus suggests it was not a very relevant crop in the region. Still, evidence for the cultivation of rye is important since it represents a change in the set of crops available. References regarding the presence of rye in northern Portugal before the Roman period (see Silva, 1988a; Oliveira, 2000) are not reliable, their chronology is uncertain, thus must not be taken into consideration.

Regarding other cereals, the abundant presence of $S$. italica in Monte Mozinho has no equivalent in northwest Iberia, but it seems that its presence in Roman sites (Monte Mozinho, São Lourenço and a single grain in Terronha de Pinhovelo) is more frequent than in Iron Age settlements. It is possible that the cultivation of this cereal was incremented in the Roman period, possibly not at an early stage, taking into consideration the chronology of the mentioned settlements.

Another difference between Iron Age and Roman contexts is the presence of more sites with $V$. vinifera, suggesting a shift toward an eventual cultivation of vine. However, the difficulties in addressing this question have been stressed before (vide supra).

The few signs of changes must be stressed but they do not change the general idea of continuity, being unclear the eventual bias of exclusive archaeobotanical studies in hillforts. Still, archaebotanical data must be analyzed together with other archaeological data and must be included in the general trends that have been identified and discussed by classical archaeology in Northern Portugal and Galicia.

Following Rui Morais (1997/1998) we consider that in the beginning of the Roman dominance in northwest Iberia, namely the first imperial dynasty, persisted, with little changes, the Iron Age settlement pattern (i.e., hillforts in hills and spurs) and its correspondent agrarian system. In these circumstances, it is normal to find signs of continuity between Iron Age and Roman agricultural choices in the hillforts, particularly when most of the data comes from 1 st century AD contexts. One example of change $-S$. cereale comes from 1st century contexts in Cruito and 3rd-4th centuries contexts in Monte Mozinho. Both sites were founded in Roman times.

However, changes occurred in the region throughout the Roman period and these included new forms of settlements. The available data is not sufficient to understand, besides mere assumption, how the changes in settlement patterning and type during the 2nd century AD were reflected in agriculture. By this time, many hillforts were abandoned and new Roman-type settlements were built and spread in the region (villae, farms, vicus), although not in an entirely homogeneous way. These must have had some impact on territorial organization and probably also on the economy of local communities. Naturally, the foundation of cities and specialized 
establishments, such as mutationes and great mining exploitations, required the existence of settlements to supply them. Still, there is a complete lack of knowledge regarding the productive strategies and eventual specialization of local villae and farms making it impossible to know how they integrated regional networks as suppliers and at what level they needed to be supplied.

Nevertheless, Martin Millet (2001) stresses the existence of few cities and the small sized villae in the region, in order to suggest the underdevelopment of typical Roman settlement patterning. Pérez Losada (2000) proposes that instead of the traditional Roman scheme city-villae, in northwest Spain there was a villae-secondary agglomerate scheme, which worked out quite differently. Other authors describe another, smaller, level of settlement for inland northern Portugal, namely small unfortified villages (Alarcão, 1998; Sande Lemos, 1993) which had productive systems directed to their self-sufficiency, with some, but minor, trade on a local level. Some hillforts that remained inhabited, usually with less population, may have had the same role as these villages (Pérez Losada, 2000). Thus, territorial organization was far more complex than the villae/farmcity scheme and, overall, the territory was rural, although in the surroundings of Bracara Augusta things could have been somehow different.

The lack of archaeobotanical studies in the new forms of settlements makes it impossible to identify eventual changes on crops and agricultural strategies. In this context, it is important to look at other facets of human subsistence, such as animal husbandry. Unfortunately, there is almost no zooarchaeological data for the conventus Bracaraugustanus so we must analyze the data available for the whole northwest Iberia, mostly from the work of Carlos Fernández Rodríguez (2000). This author documented several differences between Iron Age and Roman settlements, but these are not conspicuous in indigenous-type settlements. This is clear in the patterns of pig (Sus domesticus) consumption, much more important in the cities than in the Iron Age or Roman levels of the hillforts. Favoring the consumption of pigs is considered a Roman feature (Fernández Rodríguez, 2000). Differences exist also regarding the size of the animals - Bos taurus, Ovis aries, S. domesticus - bigger in the Roman-type settlements than in the Iron Age or Roman levels of the hillforts. Roman sites show a greater variety of animal species (domestic and wild). Thus, it is assumed that the Roman presence influenced significantly the patterns in meat consumption and that these changes are more visible in typical Roman settlements than in indigenous-type settlements, possibly suggesting the presence of some foreign people but mostly foreign influences.

Still, despite relevant differences were identified on animal husbandry, it is not correct to assume that differences on such degree existed also on the level of plant crops. The zooarchaeological data simply suggests caution is needed while analyzing archaeobotanical data, since we only have reliable data from indigenous-type of settlements, even if some were founded in Roman times.

\section{Conclusions}

Archaeobotanical data from the conventus Bracaraugustanus and northwest Iberia demonstrate the main crops were naked wheat $(T$. aestivum/durum), millet (mostly $P$. miliaceum), hulled barley $(H$. vulgare subsp. vulgare) and faba bean ( $V . f a b a)$, followed by hulled wheat (mostly $T$. turgidum subsp. dicoccum and T. aestivum subsp. spelta) and oat (Avena). Minor crops were naked barley (H. vulgare var. nudum), S. italica, rye (S. cereale), peas (P. sativum) and possibly $V$. sativa/angustifolia. Regarding the pulses, one cannot exclude the existence of eventual preservation biases.

The mentioned crops, together with archaeological data for the region, suggest the existence of continuity and innovation in the process of Romanization. In fact, the main crops from the Roman sites are, with few differences, the same as in Iron Age sites. Nevertheless, there are some significant novelties such as the first indisputable presence of rye, although it is not clear if rye had any relevant role; and the eventual cultivation of vine in the southernmost areas of the conventus. However, up to now not all the innovations usually attributed to the Romans throughout the imperial provinces are recorded in northwest Iberia, being uncertain whether it is the result of the lack of archaeobotanical studies in the region. There are no clear carpological and palynological evidence to suggest that Olea europaea was cultivated in this region and, if it was, it probably had little economical relevance.

Still, the proportion between innovation and continuity is difficult to assess since only indigenous-type settlements were studied. Continuity seems to be a characteristic of the hillforts in Roman times and, overall, the studied territory seems to have maintained its rural character, probably with a new Roman influenced kind of organization and connectivity. Furthermore, studies regarding meat consumption suggest major changes are only evident in typical Roman settlements such as cities.

Future excavations in Roman-type settlements should incorporate systematic sampling for archaeobotanical studies. Only after acquiring new data from different kind of settlements can we really understand agriculture in Roman times at the conventus Bracaraugustanus. Furthermore, such studied would allow us to appreciate at what level the Roman written agronomical knowledge was known and incorporated by local communities.

\section{Acknowledgments}

João tereso was supported by a PhD grant (SFRH/BD/41628/2007) from Fundação para a Ciência e Tecnologia. The authors wish to thank Rita Gaspar, Bruno Marcos and Ana Rita Ferreira for their help with cartographic elements and António da Silva Pereira for providing unpublished data from Cruito. At last, we thank anonymous reviewer for relevant suggestions that helped improve this article.

\section{References}

Alarcão, J., 1988. O domínio romano em Portugal. Publicações Europa-América, Mem Martins.

Alarcão, J., 1992. A evolução da cultura castreja. Conimbriga 31, 39-71.

Alarcão, J., 1998. A paisagem rural romana e alto-medieval em Portugal. Conimbriga 37, 89-119.

Almeida, C.B.d., 1996. O cultivo da vinha durante a Antiguidade Clássica na Região Demarcada do Douro. Ponto da situação. Douro - Estudos \& Documentos 1,1830.

Almeida, C.B.d., 2006. A villa do Castelum da Fonte do Milho. Uma antepassada das actuais quintas do Douro. Douro - Estudos \& Documentos 21, 209-228.

Álvarez González, Y., López González, L., 2000. La secuencia cultural del asentamiento de Laias: evolución espacial y funcional del poblado. In: Jorge, V. (Ed.), Actas do $3^{\circ}$ congresso de Arqueología Peninsular. ADECAP, Vila Real, pp. 523532

Álvarez González, Y., López González, L., López Marcos, M., 2009. La Ocupación del Espacio Común y Privado en la Citania de San Cibran de Lás. Congresso Transfronteiriço de Arqueologia, Grupo Cultural Aqva Flaviae, Montalegre. 195208.

Arnanz, A., Chamorro, J., 1990. Estudio de frutos e semillas procedentes de cuatro Castros Gallegos. Problemas de interpretación de los resultados (unpublished).

Barnard, H., Dooley, A.N., Areshian, G., Gasparyan, B., Faull, K.F., 2011. Chemical evidence for wine production around 4000 BCE in the Late Chalcolithic Near Eastern highlands. Journal of Archaeological Science 38, 977-984.

Barranhão, H., Tereso, J., 2006. A Terronha de Pinhovelo na civitas zoelarum: primeira síntese, Cadernos. In: Terras Quentes, vol. 3, pp. 7-26.

Bettencourt, A.M.S., 1999. A paisagem e o Homem na bacia do Cávado durante o II e o I milénio AC. Universidade do Minho, Braga.

Bettencourt, A.M.S., Dinis, A., Figueiral, I., Rodrigues, A., Cruz, C., Silva, I., Azevedo, M., Barbosa, R., 2007. A ocupação do território e a exploração de recursos durante a Pré-história Recente do Noroeste de Portugal. In: Jorge, S., Bettencourt, A.M.S., Figueiral, I. (Eds.), A Concepção das paisagens e dos espaços na Arqueologia da Península Ibérica. Actas do IV Congresso de Arqueologia Peninsular. Universidade do Algarve, Faro, pp. 149-164. 
Blázquez, J.M., 1967. Estructura económica de la Bética al final de la República romana y a comienzos del Imperio (años 72 a.C.-100 d.C.). Hispania 27, 7-62.

Brun, J.-P., 1997. Production de l'huile et du vin en Lusitanie Romaine. Conimbriga 36, 45-72.

Buxó, R., 1997. Arqueología de las Plantas. Crítica, Barcelona.

Buxó, R., 2005. L'agricultura d'època romana: estudis arqueobotànics i evolució dels cultius a Catalunya. Cota Zero 20, 108-120.

Buxó, R., 2008. The agricultural consequences of colonial contacts on the Iberian Peninsula in the first millennium. Vegetation History and Archaeobotany 17, 145-154.

Carrión Marco, Y., 2003. Afinidades y diferencias de las secuencias antracológicas en las vertientes mediterránea y atlántica de la Península Ibérica. In: Faculdat de Geografia i História. Universitat de Valéncia.

Carvalho, H., 2008. O povoamento romano na fachada ocidental do Conventus Bracarensis. Universidade do Minho.

Carvalho, T.P., Queiroga, F., 2005. O Castro do Mozinho: os últimos trabalhos desenvolvidos. Cadernos do Museu 11, 121-154.

Cato, Varro, 1913. Roman Farm Management. In: The Treatises of Cato and Varro Done into English, with Notes of Modern Instances by Virginia Farmer. The Macmillan Company, New York.

Coixão, A.S., 2002. Lagares e Lagaretas nas Áreas de Freixo de Numão e Murça do Douro (Concelho de Vila Nova de Foz Coa), Côavisão. Cultura e Ciência 4, 57-71.

Coixão, A.S., Silvino, T., 2006. O Sítio Arqueológico do Rumansil I (Murça do Douro, Vila Nova de Foz Côa - Portugal), Côavisão. Cultura e Ciência 8, 118-137.

Columella, L.J.M., 1960. On Agriculture. Res Rustica I-IV (H. Ash, Trans.). Harvard University Press/William Heinemann LTD.

Costa, J., Aguiar, C., Capelo, J., Lousã, M., Neto, C., 1998. Biogeografia de Portugal Continental. Quercetea 0,5-56.

Criado Boado, F., 1991. Arqueología del paisaje. In: El área Bocelo - Furelos entre los tiempos Paleolíticos y Medievales (Campañas de 1987, 1988 y 1989). Xunta de Galicia.

Dopazo Martínez, A., 1996. La dieta vegetal del Noroeste Ibérico durante el Holoceno. In: Una aproximación a través del análisis paleocarpológico. Universidad de Santiago de Compostela.

Dopazo Martínez, A., Fernández Rodríguez, C., Ramil-Rego, P., 1996. Arqueometría aplicada a yacimientos Galaico-romanos del NW Penínsular: valoración de la actividad agrícola y ganadera. In: Ramil-Rego, P., Fernández Rodríguez, C., Rodríguez Guitían, M. (Eds.), Biogeografia Pleistocena - Holocena de la Península Ibérica. Xunta de Galicia, Santiago de Compostela, pp. 317-332.

Fabião, C., 1992. O Passado Proto-Histórico e Romano. In: Mattoso, J. (Ed.), História de Portugal, 1, Antes de Portugal. Círculo de Leitores, Lisboa, pp. 77-299.

Fabião, C., 1993. A Antiguidade tardia e a desagregação do Império. In: Medina, C. (Ed.), História de Portugal dos tempos pré-históricos aos nossos dias. Ediclube, Amadora, pp. 11-32.

Fernández Rodríguez, C., 2000. Los macromamíferos en los yacimientos arqueológicos del Noroeste peninsular: un estudio económico, Facultade de Xeografía e Historia. Universidade de Santiago de Compostela, Santiago de Compostela.

Figueiral, I., 1990. Le Nord-Ouest du Portugal et les modifications de l'ecosysteme, du Bronze final a l'epoque romaine, d'apres l'anthracoanalyse de sites archeologiques. Université des Sciences et Techniques du Languedoc, Montpellier.

Figueiral, I., 2008. O Crasto de Palheiros (Murça, NE Portugal): a exploração dos recursos vegetais durante o $\mathrm{III} /$ inícios do $\mathrm{II}^{\circ}$ milénio $\mathrm{AC}$ e entre o $\mathrm{I}^{\circ}$ milénio $\mathrm{AC}$ e o séc. II $^{\circ}$ DC. In: Sanches, M. (Ed.), O Crasto de Palheiros. Fragada do Castro. Murça - Portugal. Município de Murça, Murça, pp. 79-108.

Gomes, J.M.F., Carneiro, D., 2005. Subtus Montis Terroso. Património Arqueológico no Concelho da Póvoa de Varzim. Câmara Municipal da Póvoa de Varzim, Póvoa de Varzim.

González-Ruibal, A., 2003. Arqueología del Primer Milenio a.C. en el Noroeste de la Península Ibérica. Complutense University of Madrid, Madrid.

Jacomet, S., 2006. Identification of Cereal Remains from Archaeological Sites, second ed. Archaeobotany Lab, IPAS, Basel University.

Juan Tresserras, J., Matamala, J., 2002. Análisis de materia orgánica. In: Prieto Martínez, M., Aboal Fernández, R., Ayán Vila, J. (Eds.), Arqueología en la ACEGA 1: el yacimiento galaicoromano de Agro de Ouzande (Silleda, Pontevedra). CAPA: cadernos de arqueoloxía e patrimonio, pp. 43-45.

Kimpe, K., Jacobs, P.A., Waelkens, M., 2001. Analysis of oil used in late Roman oil lamps with different mass spectrometric techniques revealed the presence of predominantly olive oil together with traces of animal fat. Journal of Chromatography A 937, 87-95.

Lemos, F., 1993. O Povoamento Romano de Trás-os-Montes Oriental. Universidade do Minho, Braga.

Lemos, F., Cruz, G., 2010. Citânia de Briteiros - perspectivas recentes sobre a romanização. In: Proceedings of the XV World Congress of the International Union for Prehistoric and Protohistoric Sciences, Lisboa, pp. 29-36.

López Cuevillas, F., 1953. In: Porto y Cía (Ed.), La Civilizacion Celtica en Galicia. Santiago de Compostela.

Martín Seijo, M., Teira Brión, A., 2010. Análise dos restos arqueobotánicos das saíñas do Areal (Vigo, Pontevedra). In: Martín Seijo, M., Rico Rey, A., Teira Brión, A. Picón Platas, I., García González, I., Abad Vidal, E. (Eds.), Guía de Arqueobotánica, Xunta de Galicia.

Martins, M., 1990. O povoamento proto-histórico e a romanização da bacia do curso médio do Cávado. Unidade de Arqueologia da Universidade do Minho, Braga.

Millet, M., 2001. Roman interaction in North-western Iberia. Oxford Journal of Archaeology 20, 157-170.

Morais, R., 1997-98. Sobre a hegemonia do vinho e a escassez do azeite no Noroeste Peninsular nos inícios da romanização. Cadernos de Arqueologia 14-15, 175182.
Morais, R., 2004. Autarcia e Comércio em Bracara Augusta no período Alto-Imperial: contribuição para o estudo económico da cidade. Universidade do Minho, Braga.

Muñoz Sobrino, C., Ramil-Rego, P., Rodríguez Guitián, M., 1997. Upland vegetation in the north-west Iberian peninsula after the last glaciation: forest history and deforestation dynamics. Vegetation History and Archaeobotany 6, 215-233.

Oliveira, M., 2000. O registo paleocarpológico do NO peninsular entre o $\mathrm{III}^{\circ}$ e o ${ }^{\circ}$ milénios a.C. In: Contributo para o estudo da alimentação pré e proto-histórica. Universidade do Minho, Braga.

Oliveira, F., Queiroga, F., Dinis, A., 1991. O pão de bolota na cultura castreja. In: Queiroga, F., Dinis, A. (Eds.), Paleoecologia e Arqueologia II. Câmara Municipal de Vila Nova de Famalicão, Vila Nova de Famalicão, pp. 251-268.

Peña Santos, A., 2005. Breve síntesis de la prehistoria e arqueología do Eixo Atlántico. In: Hidalgo Cuñarro, J. (Ed.), Rutas Arqueolóxicas do Eixo Atlántico Roteiro Arqueológico do Eixo Atlântico, Gráficas Planeta, S.L., Vigo/Porto/Bruxelles, pp. 3-42.

Pereira, A., González, C., 1988. Castro do Cruito. Arqueologia 17, 151-158.

Pérez Jordà, G., 2004. Cultivos y prácticas agrarias. In: Rodríguez Díaz, A. (Ed.), E edificio protohistórico de «La Mata » (Campanario, Badajoz) y su estado territorial. Universidad de Extremadura, Cáceres, pp. 385-422.

Pérez Losada, F., 2000. Poboamento e ocupación rural romana no noroeste peninsular (Núcleos agrupados romanos secundarios en Galicia). Universidade de Santiago de Compostela, Santiago de Compostela.

Pinho, C.F.M.d., Pinho, C.M.d., 1998. As plantas infestantes mais frequentes nas principais culturas da região de Entre Douro e Minho. IDARN. s.l.

Pollard, A., Batt, C., Stern, B., Young, S., 2007. Analytical Chemistry in Archaeology. Cambridge University Press, Cambridge.

Queiroga, F., 1992. War and Castros. In: New Approaches to the Northwestern Portuguese Iron Age. University of Oxford, Oxford.

Ramil Rego, P., 1993. Paleoethnobotánica de yacimientos arqueológicos holocenos de Galicia (N.O. Cantábrico). Munibe 45, 165-174.

Ramil Rego, P., Aira Rodríguez, M.J., 1993. A palaeocarpological study of Neolithic and Bronze Age levels of the Buraco da Pala rock-shelter (Bragança, Portugal). Vegetation History and Archaeobotany 2, 163-172.

Ramil Rego, P., Fernández Rodríguez, C., 1999. La explotación de los recursos alimenticios en el noroeste ibérico. In: García Quintela, M. (Ed.), Mitología y mitos de la Hispania prerromana (III), Akal, pp. 296-342.

Ramil Rego, P., Dopazo Martínez, A., Fernández Rodríguez, C., 1996. Cambios en las estrategias de explotación de los recursos vegetales en el Norte de la Península Ibérica. Férvedes 3, 169-187.

Ramil Rego, P., Muñoz-Sobrino, C., Rodríguez-Guitián, M., Gómez-Orellana, L., 1998. Differences in the vegetation of the North Iberian Peninsula during the last 16,000 years. Plant Ecology 138, 41-62.

Rodríguez Guitián, M., Ramil Rego, P., 2008. Fitogeografía de Galicia (NW Ibérico): análisis histórico y nueva propuesta corológica. Recursos Rurais 4, 19-50.

Rodríguez Guitián, M., Ramil-Rego, P., 2007. Clasificaciones climáticas aplicadas a Galicia: revisión desde una perspectiva biogeográfica. Recursos Rurais 1 $31-53$.

Romero Zarco, C., 1999. 33. Vicia L. In: Talavera, S., Castroviejo, S., Romero Zarco, C., Sáez, L., Salgueiro, F., Velayos, M. (Eds.), Flora Iberica. Plantas vasculares de la Península Ibérica e Islas Baleares. Real Jardín Botánico, CSIC, Madrid, pp. 360417.

Sáez Fernandez, P., 1987. Agricultura Romana de La Betica. Departamento de Historia Antigua de la Universidad de Sevilla, Sevilla.

Sampaio, J., Carvalho, A.F., 2002. Intervenção de salvamento no sítio de Bolada (S. Bartolomeu do Rêgo, Celorico de Basto). Revista Portuguesa de Arqueologia 5 29-38.

Sanches, M.J., 2008. O Crasto de Palheiros. Fragada do Crasto. Murça - Portugal. Munícipio de Murça, Murça.

Santos Yanguas, N., 1988. El ejército y la romanización de Galicia: conquista y anexión del Noroeste de la Península Ibérica. Universidad de Oviedo, Oviedo.

Silva, A.P., 1988a. A paleoetnobotânica na arqueologia portuguesa. Resultados desde 1931 a 1987. In: Queiroga, F., Sousa, I., Oliveira, C. (Eds.), Palaeocologia e Arqueologia. Câmara Municipal de Vila Nova de Famalicão, Vila Nova de Famalicão, pp. 13-29.

Silva, A.P., 1988b. Os achados de origem vegetal no campo arqueológico da Serra da Aboboreira desde 1982 a 1987. Arqueologia 17, 175-176.

Silva, A., 2007. A Terra Sigillata Hispânica Tardia de Terronha de Pinhovelo: o comércio e o povoamento. Cadernos Terras Quentes 4, 6-50.

Soeiro, T., 1998. Monte Mozinho, Sítio Arqueológico. Museu Municipal de Penafiel Penafiel.

Sousa, L., Nunes, M., Gonçalves, C., 2006. O vinho na antiguidade clássica. Alguns apontamentos sobre Lousada. Oppidum 1, 69-85.

Strabo, 1992. Geografía. Libros III-IV (M. Meana, F. Piñero, Trans.). Editorial Gredos, Madrid.

Teira Brión, A, 2010. Wild fruits, domesticated fruits. Archaeobotanical remains from the Roman saltworks at O Areal, Vigo (Galicia, Spain). In: Delhon, C., Théry-Parisot, I., Thiébault, S. (Eds.), Des hommes et des plantes. Exploitation du milieu et gestion des ressources végétales de la préhistoire à nos jours. XXX rencontres internationales d'archéologie et d'histoire d'Antibes. Éditions APDCA, Antibes, pp. 199-207.

Téllez, R., Chamorro, J., Arnanz, A., 1990. Analisis discriminante en la identificacion de trigos arqueologicos espanoles. Trabajos de Prehistoria 47, 291-318.

Tereso, J., 2007a. Paleoetnobotânica do povoado romano da Terronha de Pinhovelo (NE Transmontano), Faculdade de Ciências. Universidade do Porto, Porto. 
Tereso, J., 2007b. Economia agrícola das comunidades romanas do NW peninsular: dados carpológicos da Terronha de Pinhovelo (Bragança, Portugal). Recursos Rurais $1,13-21$.

Tereso, J., 2008a. Estudo arqueobotânico das estruturas romanas da Terronha de Pinhovelo (NE Portugal). In: Ramil Rego, E. (Ed.), Actas de 1 Congreso Internacional de Arqueoloxía de Vilalba. Museo de Prehistoria e Arqueoloxía de Vilalba, Vilalba, pp. 69-78.

Tereso, J., 2008b. A região de Macedo de Cavaleiros na Civitas Zoelarum: dados de investigações recentes. In: Ramil Rego, E. (Ed.), Actas de 1 Congreso Internacional de Arqueoloxía de Vilalba. Museo de Prehistoria e Arqueoloxía de Vilalba, pp. $431-440$

Tereso, J., 2009a. Plant macrofossils from the Roman settlement of Terronha de Pinhovelo, northwest Iberia. Vegetation History and Archaeobotany 18, 489-501.

Tereso, J., 2009b. Estudo paleoetnobotânico das estruturas romanas da Terronha de Pinhovelo (Macedo de Cavaleiros), Cadernos. In: Terras Quentes, vol. 6, pp. $81-90$

Tereso, J., 2012. Environmental Change, Agricultural Development and Social Trends in NW Iberia from the Late Prehistory to the Late Antiquity. Biology Department, Faculty of Sciences, University of Porto, Porto.
Tereso, J., Almeida, A., Almeida, C.B.d., Ramil Rego, P., Vaz, F., Almeida da Silva, R., 2010a. Estudo carpológico do castro de São Lourenço (Esposende): primeiros resultados/fruits and seeds from Castro de São Lourenço (Esposende, northwest Portugal): first results. Estudos do Quaternário 6, 67-73.

Tereso, J., Carvalho, T.P., Almeida da Silva, R., Ramil Rego, P., 2010b. Cultivos e armazenagem em Monte Mozinho: dados preliminares. In: Bettencourt, A.M.S. Alves, M.I.C., Monteiro-Rodrigues, S. (Eds.), Variações paleoambientais e evolução antrópica no Quaternário do Ocidente Peninsular/Palaeoenvironmental Changes and Anthropization in the Quaternary of Western Iberia. Associação Portuguesa para o Estudo do Quaternário. APEQ e Centro de Investigação Transdisciplinar. Cultura, Espaço e Memória - CITCEM, Braga, pp. 149-158.

Tereso, J., Ramil Rego, P., Almeida da Silva, R., 2011. A exploração de recursos alimentares silvestres e seu enquadramento nas dinâmicas económicas e sociais das comunidades agrícolas desde a Pré-história à época romana. In: Tereso, J., Honrado, J., Pinto, A.T., Rego, F.C. (Eds.), Florestas do Norte de Portugal. História, Ecologia e Desafios de gestão. InBio - Rede de Investigação em Biodiversidade e Biologia Evolutiva, Porto.

Tranoy, A., 1981. La Galice Romaine: Recherches sur le Nord-Ouest de la Péninsule Ibérique dans l'Antiquité. Diffusion E. du Boccard, Paris. 